\title{
MUTU HEDONIK DAN KIMIA IKAN TERI (Stolephorus commersonii) ASAP CAIR
}

\author{
Rieny Sulistijowati ${ }^{\star 1} ;$ Rahmad Arianto Rivai ${ }^{1}$ \\ 1 Jurusan Teknologi Hasil Perikanan, Fakultas Perikanan dan IImu Kelautan, Universitas Negeri Gorontalo, \\ J..Jenderal Sudirman No.06, Kota Gorontalo 96128, Gorontalo, Indonesia \\ *Korespondensi: rienysulistijowati@ung.ac.id \\ (Diterima 13-02-2020/ Dipublikasi 13-02-2020)
}

\begin{abstract}
ABSTRAK
Penelitian ini bertujuan untuk mengetahui mutu hedonik dan kimia ikan teri (stolephorus commersonii) asap cair dengan lama perendaman yang berbeda. Perlakuan pada penelitian ini adalah lama perendaman ikan teri asap cair dengan konsentrasi 1,5\% dan lama perendaman yaitu 5 menit, 10 menit, dan 15 menit. Penelitian ini dirancang menggunakan metode Multirater Rasch Model untuk mendapatkan data hasil organoleptik mutu hedonik dan dianalisis dengan Minifac, data - data hasil kimia diperoleh melalui Rancangan Acak Lengkap (RAL) dan dianalisis dengan Compare Means One-Way ANOVA. Hasil analisis Anova dilanjutkan dengan uji lanjut Duncan. Hasil penelitian mutu organoleptik menunjukkan bahwa Ikan teri asap cair dengan lama perendaman berbeda yang terbaik yaitu 15 menit memiliki kenampakan yaitu utuh, bersih, rapi, seragam, cemerlang, sangat menarik; aroma asap cair yaitu segar, spesifik jenis tanpa aroma tambahan; tekstur yaitu padat, kompak, antar jaringan sangat erat; rasa yaitu segar spesifik jenis tanpa rasa tambahan. Sedangkan pada hasil analisis mutu kimia memberikan pengaruh nyata pada kadar air dan kadar fenol dengan nilai 7,86 \%, 0,0279\%.
\end{abstract}

Kata Kunci : Kadar Air; Kadar Fenol; Mutu Hedonik; Ikan Teri (Stolephorus commersonii); Asap Cair.

\section{ABSTRACT}

This study aims to understand the quality and chemistry of anchovy (Stolephorus commersonii) as soon as possible with different soaking times. The treatment in this study was the duration of soaking liquid anchovy with a concentration of $1.5 \%$ and the duration of soaking was 5 minutes, 10 minutes, and 15 minutes. This study was designed using the Rasch Multirater Model method to obtain organoleptic data that is supported by hedonics and analyzed by Minifac, chemical processing using a Completely Randomized Design (CRD) and analyzed by Compare Mean OneWay ANOVA. The results of the analysis continued with Duncan's further tests. Organoleptic quality research results show that liquid smoked anchovy with the best soaking time is 15 minutes that has an appearance that is whole, clean, neat, uniform, brilliant, very attractive; liquid smoke scent that is fresh, special types without additional scents; dense texture, dense, between networks is very tight; additional taste without flavor type without additional flavor. While the results of the analysis of chemical levels have a significant effect on water content and phenol content with a value of $7.86 \%$, $0.0279 \%$.

Key Words: Water content; Phenol content; Hedonic quality; Stolephorus commersonii; Liquid smoke 


\section{PENDAHULUAN}

Ikan teri (Stolephorus commersonii) merupakan salah satu sumber daya hayati laut yang tersedia hampir di seluruh perairan Indonesia dan merupakan salah satu komoditas sektor perikanan laut yang cukup melimpah. Produksi ikan teri secara nasional dalam periode $2000-2010$ sebesar $11,89 \%$ (Fauzya dkk, 2012). Berdasarkan Data Statistik Dinas Kelautan dan Perikanan (DKP) Provinsi Gorontalo (2013), produksi hasil tangkapan ikan teri pada tahun 2012 mencapai 6,293 Ton. Dari jumlah total tangkapan tersebut, 3,22 Ton diolah dalam bentuk ikan kering dan sisanya dijual dalam bentuk segar.

Ikan teri segar mengandung gizi yang cukup tinggi khususnya protein sebesar $16 \%$ dan kalsium sebesar 500 mg (BKKP, 2012). Namun pemanfaatan ikan teri di provinsi Gorontalo dinilai masih cukup minim sebab ikan teri umumnya hanya diolah menjadi teri kering yaitu sebesar $51,4 \%$. Apabila hasil tangkapan teri melimpah pada saat tertentu, maka masyarakat hanya pada satu pengolahan yakni pengeringan. Sedangkan hasil produk teri kering juga cepat megalami kemunduran mutu akibat proses pengeringan yang kurang tepat.

Menurut Adawyah (2007) bahwa umumnya kerusakanpada ikan kering yang diberi garam atau tanpa garam dapat disebabkan karena adanya aktivitas bakteri halofilik yang mampu mengubah tekstur dan kenampakan dari ikan. Selain itu ikan yang dikeringkan sangat sering terjadi kerusakan karena adanya pertumbuhan kapang, hal ini menjadi salah satu indikator penurunan mutu dari produk ikan kering. Penyebab kerusakan mutu produk perikanan olahan tradisional adalah adanya aktivitas jamur (kapang dan khamir). Hal tersebut menunjukkan bahwa perlu adanya metode pengolahan pengeringan yang juga dapat mengawetkan ikan kering, salah satunya yaitu dengan menggunakan pengasapan cair.

Menurut Alcicek (2011) asap cair dapat digunakan sebagai pengawet makanan karena adanya sifat antimikroba dan antioksidan senyawa, seperti aldehid, asam karboksilat dan fenol. Teknik pengasapan dengan menggunakan asap cair memiliki beberapa keuntungan dibandingkan dengan teknik pengasapan tradisional. Pengasapan dengan asap cair mudah, cepat, keseragaman produk, karakteristik makanan yang didapatkan baik serta tidak terdepositnya senyawa karsinogenik hidrokarbon aromatik polisiklik dalam makanan yang diawetkan.

Asap cair mengandung berbagai senyawa yang terbentuk karena terjadinya pirolisis tiga komponen kayu yaitu : selulosa, hemiselulosa, dan ignin. Lebih dari 400 senyawa kimia dalam asap telah berhasil 
diidentifikasi. Proses pengasapan cair, aroma asap yang akan dihasilkan pada proses pengasapan didapat tanpa melalui proses pengasapan, melainkan melalui penambahan cairan bahan pengasap (smoking agent) ke dalam produk. Baha baku ikan direndam dalam wood acid, yang didapat dari hasil ekstrak penguapan kering unsur kayu atau dari hasil ekstrak yang ditambahi pewangi kayu, yang hampir sama dengan aroma pada pengasapan, setelah itu ikan dikeringkan dan menjadi produk akhir. Metode penambahan bahan pengasap ke dalam ikan, dapat dilakukan melalui penuangan langsung, pengasapan, pengolesan atau penyemprotan. Melalui proses ini tidak diperlukan lagi ruang tempat pengasapan atau alat pengasap yang menjadi keuntungan dari proses ini, namun aroma produk yang dihasilkan jauh di bawah dari aroma produk yang dilakukan dengan proses pengasapan sesungguhnya (Sulistijowati, $d k k, 2011$ ).

Berdasarkan latar belakang yang telah diuraikan maka, penulis melakukan penelitian mengenai pengolahan ikan teri dengan metode pengasapan cair dengan harapan bahwa ikan teri yang dihasilkan akan memiliki daya awet yang lebih lama.

\section{METODE PENELITIAN}

\section{Waktu dan Tempat}

Penelitian ini dilaksanakan pada bulan Januari - Agustus Tahun 2017. Tempat pelaksanaan penelitian untuk pembuatan ikan teri asap cair dan pengujian organoleptik dilakukan di Laboratorium Bioteknologi dan Karakteristik Hasil Perikanan, Jurusan Teknologi Hasil Perikanan Fakultas Perikanan dan IImu Kelautan Universitas Negeri Gorontalo. Pengujian kimia dan mikrobiologi sampel dilakukan di Balai Pengawasan dan Pengujian Mutu Hasil Perikanan Kota Gorontalo.

\section{Alat dan Bahan}

Alat yang digunakan dalam pembuatanikan teri asap cair yaitu termometer, timbangan analitik, gelas ukur, wadah, ATK, camera serta pengering mekanik. Alat yang digunakan dalam analisis organoleptik yaitu bilik, tissue, camera, wadah dan score sheet hedonik dan mutu hedonik berdasarkan (SNI: 2346-2011). Alat untuk analisis fenol yaitu labu ukur, pipet, Erlenmeyer, timbangan analitik, gegap (tang penjepit). Alat untuk analisis kadar air antara lain mortir steril, oven, cawan, desikator, termometer, timbangan analitik, gegap (tang penjepit).

Bahan yang digunakan dalam pembuatan ikan teri asap cair yaitu ikan teri segar dengan ukuran panjang 5-7 cm dengan berat $250 \mathrm{~g}$ dan asap cair tempurung kelapa komersil asap cair pekat konsentrasi fenol $2 \%$ dan aquades sebagai pelarut dalam pembuatan larutan asap cair. Bahan yang digunakan 
untuk analisis organoleptik yaitu ikan teri asap cair Bahan yang digunakan untuk analisis kadar fenol antara lain sampel ikan teri, $\mathrm{NaOH}, \mathrm{KBrO}_{3}, \mathrm{Na}_{2} \mathrm{~S}_{2} \mathrm{O}_{3}, \mathrm{HCL}$ pekat alkali $2 \%$ aquades.

Metode yang di gunakan pada penelitian ini adalah Metode eksperimen dengan menggunakan Rancangan Acak Lengkap (RAL). Menurut Solso dan Maclin (2002) dalam Ibrahim (2014) metode eksperimen adalah suatu penelitian yang didalamnya ditemukan minimal satu variabel yang dimanipulasi untuk mempelajari hubungan sebab-akibat dalam rangka mencari pengaruh hubungan maupun perbedaan perubahan terhadap kelompok yang dikenakan perlakuan.

\section{Prosedur Penelitian}

Pembuatan ikan teri asap cair diawali dengan melakukan permbersihan menggunakan air bersih, tujuannya yaitu untuk mengeluarkan kotoran-kotoran yang menempel serta mencegah terjadinya pertumbuhan bakteri, sehingga mutu akhir produk tetap aman. Ikan teri yang sudah dibersihkan ditimbang dengan timbangan analitik dengan berat ikan sebesar $250 \mathrm{~g}$. Ukuran dan berat ikan yang digunakan dalam penelitian harus seragam. Selanjutnya asap cair tempurung kelapa komersil yang berasal dari pedagang di Sulawesi utara dibuat konsentrasi $1,5 \%$ dengan lama waktu perendaman yang digunakan yaitu selama 5 menit, 10 menit, dan 15 menit.

Konsentrasi asap cair yang digunakan didapat dengan cara pengenceran larutan asap cair sesuai dengan rumus pengenceran. Setelah dilakukan perendaman dalam asap cair ikan teri ditiriskan atau diangin-anginkan selama 15 menit. Setelah dilakukan penirisan dilanjutkan dengan proses pengeringan yaitu dengan tujuan untuk menguapkan air yang berada dalam daging ikan teri, sehingga mencapai kadar air tertentu agar kerusakan bahan pangan dapat diperlambat (Tuina, 2013). Proses pengeringan ini dilakukan dengan cara ikan dimasukan ke dalam pengering mekanik dengan menata ikan-ikan tersebut agar dalam proses pengeringan panas yang diberikan akan merata. Suhu yang digunakan dalam pengering mekanik yaitu $40-50^{\circ} \mathrm{C}$ dengan lama pengeringan selama 4 jam. Setelah pengeringan selama 4 jam dihasilkan ikan teri asap cair kering dan dilakukan pengujian organoleptik di Laboratorium Perikanan dan IImu Kelautan Universitas Negeri Gorontalo berdasarkan score sheet hedonik dan mutu hedonik. Prosedur pengujian yang dilakukan pada ikan teri asap cair kering yaitu melalui uji organoleptik mutu hedonik, uji mutu kimia dan uji mikrobiologi. 


\section{HASIL DAN PEMBAHASAN}

Organoleptik Mutu Hedonik Ikan Teri (S. commersonii) Asap Cair

Pengujian organoleptik ikan teri yang direndam asap cair dengan perlakuan A (5 menit), B (10 menit), C (15 menit) menggunakan pengujian mutu hedonik dengan 25 orang panelis. Hasil pengujian organoleptik mutu hedonik meliputi kenampakan, tekstur, aroma dan rasa. Pengujian organoleptic (Mutu Hedonik) dengan menggunakan Rasch Model dapat dilihat pada Gambar 1.

\section{Kenampakan}

Hasil uji RASCH Model menunjukkan bahwa nilai mutu hedonik terhadap kenampakan ikan teri asap cair yang direndam dengan waktu berbeda berada pada interval 1-9. Nilai paling rendah terdapat pada lama perendaman 5 menit yaitu nilai 5 dengan kriteria tidak utuh, kurang bersih, kurang rapi, tidak seragam, kusam, tidak menarik, pada lama perendaman 10 menit yaitu nilai 7 dengan kriteria utuh, bersih, kurang rapi, seragam, agak cemerlang, menarik dan nilai tertinggi terdapat pada lama perendaman 15 menit yaitu nilai 9 dengan kriteria utuh, bersih, rapi, seragam, cemerlang, sangat menarik. Hal ini dibuktikan dengan hasil analisis probability bahwa nilai mutu hedonik terbaik terhadap kenampakan ikan teri asap cair yaitu direndam dengan waktu 15 menit (Sampel C) berada pada nilai 9 dengan persentase $60 \%$.

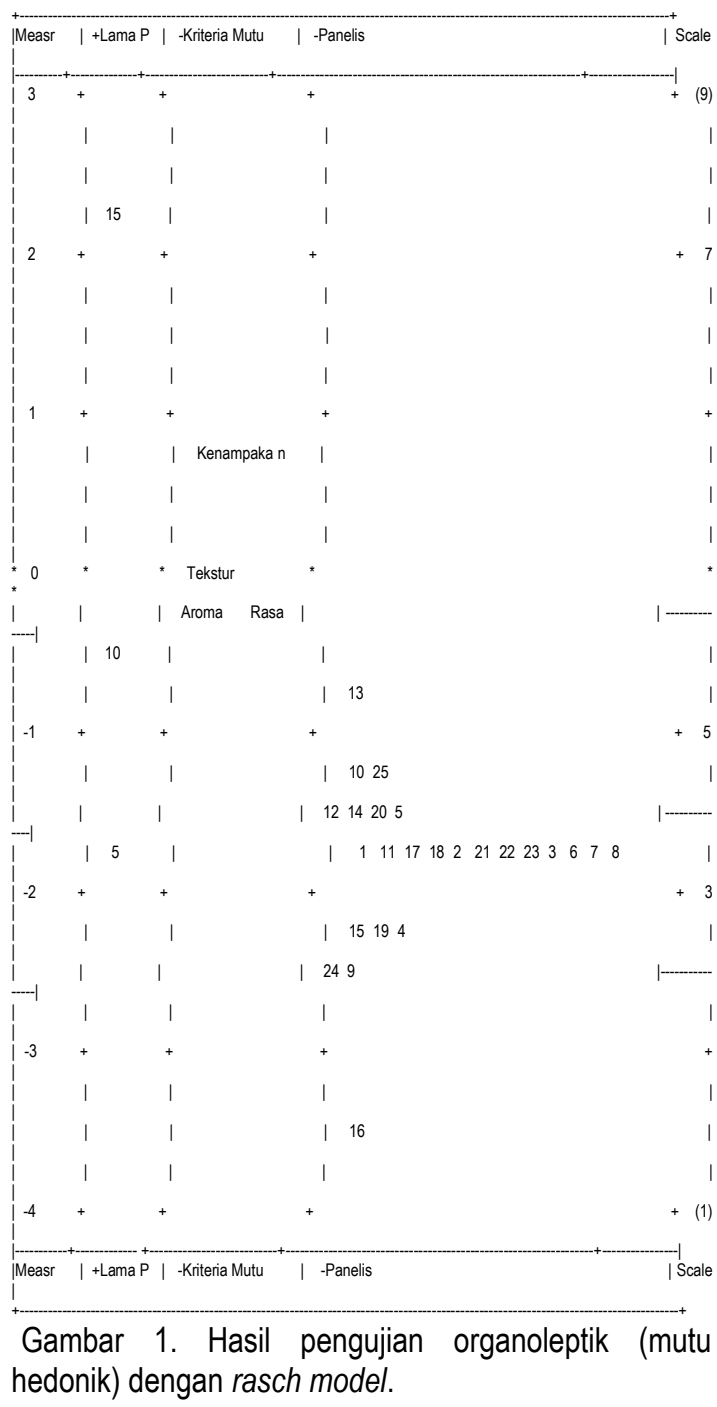

Hasil penelitian dari ikan teri asap cair dengan lama perendaman yang berbeda dapat dilihat pada Gambar 2.

Hasil penelitian menunjukkan bahwa semakin lama perendaman, nilai organoleptik kenampakan ikan teri asap cair semakin meningkat. Hal ini disebabkan semakin lama perendaman asap cair yang diberikan, maka komponen asap yang meresap ke dalam daging ikan teri semakin banyak, sehingga warna produk semakin coklat cemerlang. Hal ini disebabkan 
oleh senyawa karbonil, jenis karbonil yang terdapat dalam asap cair antara lain adalah vanillin dan syring-aldehyde (Moejiharto dkk, 2000).

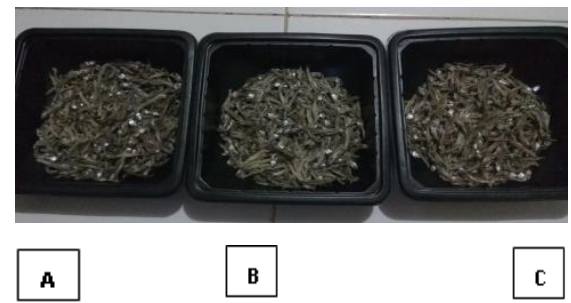

Gambar 2. Kenampakan dari 3 sampel ikan teri asap cair dengan lama perendaman yang berbeda

Keterangan:

$\mathrm{A}=$ Ikan teri asap cair lama perendaman 5 menit

$B=I k a n$ teri asap cair lama perendaman 10 menit

$C=I k a n$ teri asap cair lama perendaman 15 menit
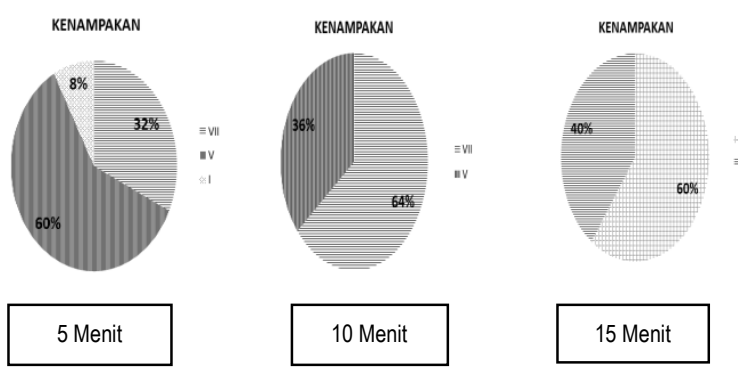

Gambar 3. Analisis probability sampel ikan teri asap cair pada kenampakan

Menurut Maga (1988) dalam Ayudiarti dan Sari (2010), kenampakan dari ikan asap terbentuk akibat dari reaksi gugus karbonil yang terkandung dalam asap bereaksi dengan protein dan lemak dalam ikan sehingga ikan asap menjadi nampak berwarna coklat, hal tersebut juga dihasilkan dari reaksi fenol dengan oksigen di udara. Peran asap dalam hal ini memberikan pengaruh terhadap nilai organoleptik, disebabkan oleh reaksi dari asam, fenol, dan kandungan lainnya dalam asap dengan lemak, protein dan karbohidrat (Cardinal et al., 2006; Swastawati, 2008)

\section{Aroma Asap Cair}

Hasil uji RASCH Model menunjukkan bahwa nilai mutu hedonik terhadap aroma ikan teri asap cair yang direndam dengan waktu berbeda berada pada interval $1-9$. Lama perendaman 5 menit yaitu memiliki nilai 7 dengan kriteria segar, spesifik jenis berkurang tanpa aroma tambahan, dan pada lama perendaman 10 menit yaitu nilai 7 dengan kriteria segar, spesifik jenis berkurang tanpa aroma tambahan sedangkan nilai tertinggi terdapat pada lama perendaman 15 menit yaitu nilai 9 dengan kriteria segar, spesifik jenis tanpa aroma tambahan. Hal ini dibuktikan dengan hasil analisis probability bahwa nilai mutu hedonik terbaik terhadap kenampakan ikan teri asap cair yaitu direndam dengan waktu 15 menit (Sampel C) berada pada nilai 9 dengan persentase $64 \%$ (Gambar 4).
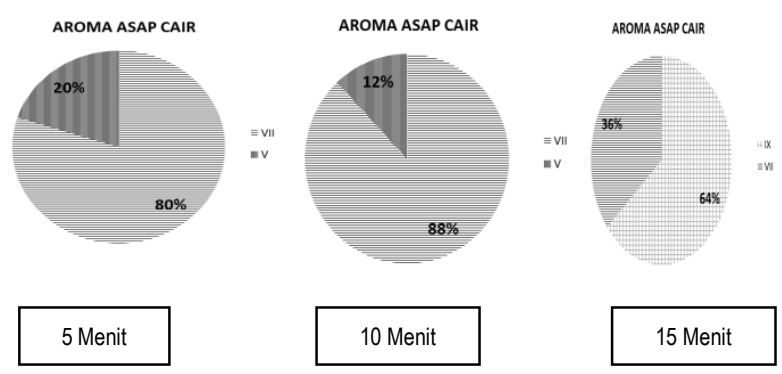

Gambar 4. Analisis probability sampel ikan teri asap cair pada aroma asap cair

Hasil penelitian menunjukkan bahwa semakin lama perendaman, nilai organoleptik aroma ikan teri asap cair semakin kuat. Hal tersebut dapat dipengaruhi oleh senyawa aromatik seperti lignin yang dihasilkan dari 
asap cair tempurung kelapa yang meresap masuk dalam jumlah yang lebih banyak dari pada lama perendaman 5 dan 10 menit. Himawati (2010) dalam Rasyda (2013) menyatakan bahwa komposisi utama yang terdapat dalam tempurung kelapa adalah hemisellulosa, sellulosa dan lignin.

Lignin terdiri dari sistem aromatik yang tersusun atas unit-unit fenilpropana. Senyawa-senyawa yang diperoleh dari pirolisis struktur dasar lignin berperan penting dalam memberikan aroma asap pada produk ikan asap. Kandungan lignin untuk tiap-tiap tumbuhan yang berbeda akan bervariasi, namun secara umum kandungan lignin yang terdapat dalam kayu keras berkisar antara 20- $40 \%$ (Yulstiani, 2008).

Menurut Soeparno (2005) dalam Dwiyitno dkk (2006) mengemukakan pula bahwa bau khas tersebut adalah fenol yaitu senyawa utama pembentuk aroma asap. Moejiharto $d k k$ (2000) menjelaskan bahwa besarnya kadar fenol berhubungan dengan semakin besarnya konsentrasi perendaman. Hal ini dapat dijelaskan bahwa difusi asap cair (fenol) dari permukaan ke pusat sampel berjalan sesuai dengan besarnya lama perendaman yang diberikan. Dwiyitno $d k k$, (2006) menyatakan bahwa aroma khas yang timbul atau terdeteksi pada produk ikan asap, dapat berasal dari senyawa fenol (senyawa utama pembentuk aroma asap).

\section{Tekstur}

Hasil uji RASCH Model menunjukkan bahwa nilai mutu hedonik terhadap tekstur ikan teri asap cair yang direndam dengan waktu berbeda berada pada interval $1-9$. pada lama perendaman 5 menit yaitu memiliki nilai 7 dengan kriteria padat, kompak, antar jaringan cukup erat dan pada lama perendaman 10 menit yaitu memiliki nilai 5 dengan kriteria agak rapuh, kurang kompak, antar jaringan kurang erat dan nilai tertinggi terdapat pada lama perendaman 15 menit yaitu nilai 9 dengan kriteria padat, kompak, antar jaringan sangat erat. Hal ini dibuktikan dengan hasil analisis probability bahwa nilai mutu hedonik terbaik terhadap kenampakan ikan teri asap cair yaitu direndam dengan waktu 15 menit (Sampel C) berada pada nilai 9 dengan persentase 64\% (Gambar 5).
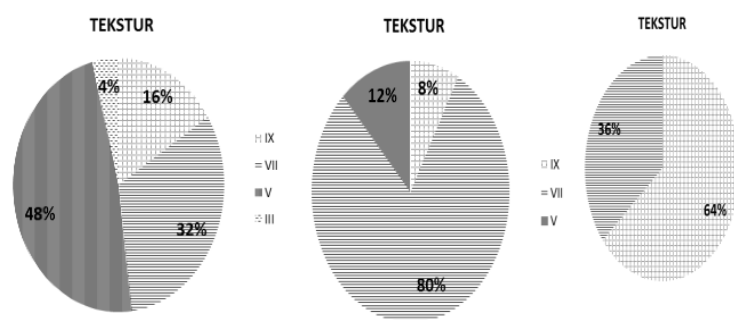

$$
5 \text { Menit }
$$

$$
10 \text { Menit }
$$

Gambar 5. Analisis probability sampel ikan teri asap cair pada tekstur.

Hasil penelitian menunjukkan bahwa semakin lama perendaman menggunakan asap cair, nilai organoleptik tekstur semakin tinggi. Hal ini diduga karena kadar air yang terdapat pada ikan sudah mulai berkurang 
hingga batas optimal pengeringan ikan (4 jam), sehingga didapatkan tekstur yang padat dan kompak untuk ikan teri asap cair. Sulistijowati $d k k$ (2011) meyatakan bahwa semakin rendah jumlah kadar air pada ikan asap maka nilai teksturnya semakin tinggi. Hal ini dikarenakan daging ikan semakin padat atau keras seiring menurunya kadar air dari tubuh ikan.

Menurut Purnomo (1995), bahwa kadar air dan aktivitas air dalam bahan pangan sangat besar peranannya terutama dalam menentukan tekstur bahan pangan. Hal ini sesuai dengan apa yang dikemukakan oleh Rahman (2007) yaitu otot dan sel ikan akan mengkerut akibat keluarnya air dari ikan setelah proses dehidrasi osmosis. Keluarnya air karena kadar phenol bersifat sebagai pembentuk tekstur ikan menjadi kering, hal ini dapat dilihat pada gambar 6 (kadar air ikan teri asap cair).

\section{Rasa}

Hasil uji RASCH Model menunjukkan bahwa nilai mutu hedonik terhadap rasa ikan teri asap cair yang direndam dengan waktu berbeda berada pada interval $1-9$. Nilai paling rendah terdapat pada lama perendaman 5 menit yaitu nilai 7 dengan kriteria segar spesifik jenis berkurang tanpa rasa tambahan dan pada lama perendaman 10 menit yaitu memiliki nilai 7 dengan kriteria segar spesifik jenis berkurang tanpa rasa tambahan sedangkan nilai tertinggi terdapat pada lama perendaman 15 menit yaitu nilai 9 dengan kriteria segar spesifik jenis tanpa rasa tambahan. Hal ini dibuktikan dengan hasil analisis probability bahwa nilai mutu hedonik terbaik terhadap kenampakan ikan teri asap cair yaitu direndam dengan waktu 15 menit (Sampel C) berada pada nilai 9 dengan persentase 52\% (Gambar 6).

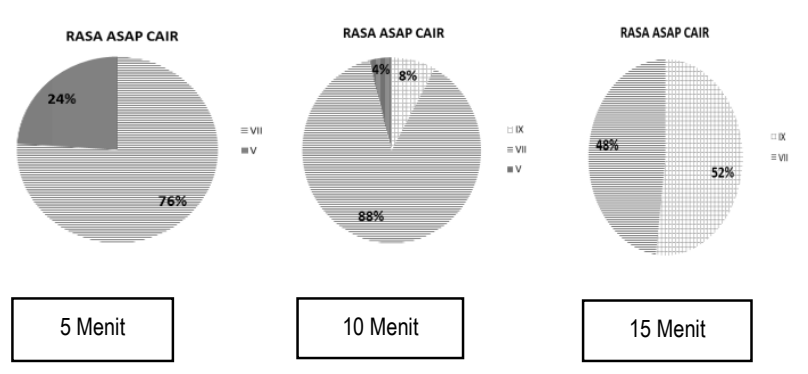

Gambar 6. Analisis probability sampel ikan teri asap cair pada rasa asap cair.

Hasil penelitian menunjukkan bahwa semakin lama ikan teri direndam dengan asap cair, semakin tinggi nilai organoleptik rasa asap cair. Hal ini diduga dipengaruhi oleh lama waktu perendaman yang diberikan menghasilkan senyawa karbonil cukup banyak sehingga meresap kedalam komponen jaringan daging ikan dan bereaksi dengan senyawa asam amino pada ikan teri, sehingga citarasa ikan teri asap menjadi meningkat. sesuai dengan pernyataan Refilda (2008), bahwa penggunaan asap cair pada sampel ikan memberikan rasa khas asap cair. Hal ini disebabkan oleh senyawa karbonil yang memberikan pengaruh cita rasa spesifik pada ikan teri asap cair, sehingga rasa amis ikan dapat tertutupi. Komponen dalam asap cair yang dapat menimbulkan rasa sedap 
pada produk yaitu formaldehide dan furaldehide (Darmadji, 2009).

\section{Mutu Kimia Ikan Teri (S. commersonii) Asap Cair}

Hasil pengujian mutu kimiawi ikan teri yang direndam dengan asap cair meliputi kadar air dan kadar fenol dapat dilihat pada Tabel 1.

Tabel 1. Hasil pengujian kimiawi ikan teri commersonii) asap cair

\begin{tabular}{lccc}
\hline \multirow{1}{*}{$\begin{array}{c}\text { Kriteria } \\
\text { Pengujian }\end{array}$} & \multicolumn{3}{c}{ Hasil Penelitian } \\
\cline { 2 - 4 } & $\begin{array}{c}\mathrm{A}(5 \\
\text { menit) }\end{array}$ & $\begin{array}{c}\mathrm{B}(10 \\
\text { menit) }\end{array}$ & $\begin{array}{c}\mathrm{C}(15 \\
\text { menit })\end{array}$ \\
\hline $\begin{array}{l}\text { Kadar air (\%) } \\
\text { Kadar fenol } \\
(\%)\end{array}$ & 14,46 & 9,09 & 7,86 \\
\hline
\end{tabular}

\section{Kadar Air}

Kadar air dapat dihitung sebagai persentase kandungan air suatu bahan yang dinyatakan dalam basis basah atau kering. Histogram kadar air hasil analisis ikan teri asap cair masing-masing perlakuan dapat dilihat pada Gambar 6.

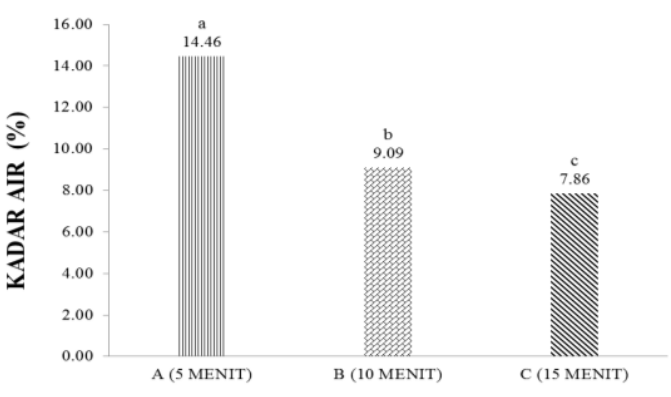

LAMA PERENDAMAN

Gambar 7. Histogram kadar air ikan teri (S. commersonii) dengan lama perendaman asap cair yang berbeda.

Gambar 7 menunjukkan kadar air berada pada kisaran 7,86\%-14,46\%. Nilai kadar air tertinggi terdapat pada formula A (5 menit) yaitu $14,46 \%$. Sedangkan kadar air terendah terdapat pada formula $C$ (15 menit) yaitu 7,86\%. Berdasarkan SNI ikan asap nomor 2725.(1)1:2009, kadar air ikan teri asap cair memenuhi SNI yaitu maksimal $60 \%$ (Tabel 4).

Berdasarkan hasil uji ANOVA lama perendaman dengan asap cair memberikan pengaruh nyata dapat menurunkan kadar air ikan teri asap cair. Hasil uji Duncan menunjukkan bahwa kadar air formula $A, B$, dan $\mathrm{C}$ semua berbeda nyata.

Semakin lama waktu perendaman ikan teri dengan asap cair, semakin sedikit kadar air yang dihasilkan. Hal ini disebabkan oleh jumlah kadar air yang diuapkan dalam komponen jaringan daging ikan teri semakin banyak. Perbedaan lama perendaman akan menghasilkan kadar air pada ikan teri asap cair berbeda. Hal ini akan menimbulkan perbedaan jumlah kandungan fenol yang terserap pada daging ikan. Waktu perendaman yang lebih lama akan memiliki kadar air yang rendah akan menghasilkan jumlah fenol yang lebih tinggi. Hal ini terjadi karena disebabkan oleh larutan asap cair yang masuk kedalam daging secara osmosis sehingga air bebas yang terdapat dalam daging ikan terdesak keluar. Kadar air bebas dalam daging ikan semakin menurun dan jumlah asap cair yang masuk kedalam daging 
ikan semakin meningkat seiring lama perendaman daging dalam larutan asap cair (Andhika, 2014).

Setha (2011) menyatakan bahwa daging ikan yang direndam dalam larutan asap cair akan mengalami penurunan kadar air akibat proses osmosis, jumlah air bebas yang terdapat dalam daging ikan akan semakin berkurang akbat masuknya komponen asap. Menurut Mahendradatta (2006), banyak sedikitnya fenol yang terserap kedalam daging ikan dapat mempengaruhi percepatan penguapan air pada daging ikan karena penambahan senyawa fenol dapat mempengaruhi penurunan kadar air.

\section{Kadar Fenol}

Histogram kadar fenol hasil analisis ikan teri asap cair masing-masing perlakuan dapat dilihat pada Gambar 8.

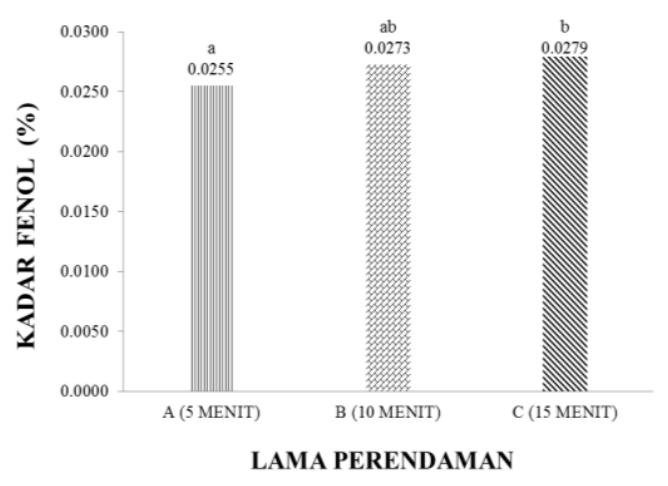

Gambar 8. Histogram kadar fenol ikan teri (S. commersonii) dengan lama perendaman asap cair yang berbeda.

Gambar 8 menunjukkan kadar fenol berada pada kisaran 0,0255\%-0,0279\%. Nilai kadar fenol tertinggi terdapat pada formula $\mathrm{C}$ (15 menit) yaitu $0,0279 \%$. Sedangkan kadar fenol terendah terdapat pada formula A (5 menit) yaitu $0,0255 \%$. Berdasarkan SNI ikan asap nomor 2725.(1)1:2009, kadar fenol ikan teri asap cair tidak disyaratkan (Tabel 4), tetapi berdasarkan Girard (1992) dalam Ernawati (2012), menyatakan bahwa jumlah batas aman fenol dalam produk asapan berkisar dari $0,06 \mathrm{mg} / \mathrm{kg}$ sampai $5000 \mathrm{mg} / \mathrm{kg}$ atau 6 ppm sampai 5000 ppm (0,0006 $0,5 \%)$.

Berdasarkan hasil uji ANOVA lama perendaman dengan asap cair yang berbeda memberikan pengaruh nyata terhadap kadar fenol ikan teri. Hasil uji Duncan menunjukkan bahwa kadar fenol formula A tidak berbeda nyata dengan formula $B$ tetapi berbeda nyata dengan formula C. Namun kadar fenol formula B tidak berbeda nyata dengan formula $\mathrm{C}$.

Semakin lama perendaman dalam asap cair semakin meningkat kadar fenol dari ikan teri. Hal ini diduga disebabkan karena semakin lama perendaman dapat mempengaruhi banyaknya senyawa fenol yang terserap sampai ke titik pusat daging ikan teri. Hasil ini sesuai dengan penelitian Haras (2004) yang menyatakan bahwa semakin lama perendaman ikan dalam asap cair, maka semakin meningkat kadar fenol dalam daging ikan. 
Fenol dan turunannya menjadi senyawa paling dominan pada asap cair tempurung kelapa. Hal ini, dikarenakan komponen paling dominan pada komposisi kimia tempurung kelapa adalah lignin. Menurut Djatmiko et al., (1985) komposisi kimia paling dominan pada tempurung kelapa adalah lignin dengan konsentrasi sebesar $33,30 \%$. Senyawa fenol sangat penting dalam produk asap, karena fenol berperan dalam menyumbangkan aroma dan rasa spesifik produk asapan (Guillen et al, 2002).

Fenol merupakan zat aktif yang dapat memberikan efek antibakteri pada asap cair. Selain itu, fenol juga memberikan efek antioksidan pada bahan makanan yang akan diawetkan. Identifikasi fenol terhadap kualitas asap cair yang dihasilkan dapat mewakili kriteria dari mutu asap cair tersebut, sehingga hasilnya bisa diaplikasikan pada semua produk pengasapan. Yulistiani (2008) mendapatkan data kandungan fenol dalam asap cair tempurung kelapa sebesar 1,28\%. Gumanti (2006) mendapatkan data kandungan senyawa kimia dalam asap cair yaitu fenol sebesar 5,5\%, methyl alkohol $0,37 \%$, dan total asam sebesar $7,1 \%$.

\section{SIMPULAN}

Berdasarkan hasil penelitian dapat disimpulkan bahwa lkan teri asap cair dengan lama perendaman berbeda yang terbaik yaitu 15 menit (konsentrasi 1,5\% asap cair) memiliki kenampakan yaitu utuh, bersih, rapi, seragam, cemerlang, sangat menarik; aroma asap cair yaitu segar, spesifik jenis tanpa aroma tambahan; tekstur yaitu padat, kompak, antar jaringan sangat erat; rasa yaitu segar spesifik jenis tanpa rasa tambahan, sedangkan pada hasil analisis mutu kimia memberikan pengaruh nyata pada kadar air, kadar fenol, dan total bakteri, dengan nilai $7,86 \%, 0,0279 \%, 4,33 \mathrm{CFU} / \mathrm{g}$.

\section{DAFTAR PUSTAKA}

Adawyah, R. 2007. Pengolahan dan Pengawetan Ikan. Jakarta : Bumi Aksara.

Andhika, R. 2014. Pengaruh perbedaan konsentrasi dan lama perendaman dalam larutan asap cair hasil pirolisis kulit kacang tanah (Arachis hypogea) terhadap mutu ikan baung (Mystus nemurus) asap. FPIK. Universitas Riau.

Alcicek, Z., 2011, The Effects of Thyme (Thymus vulgaris L.) Oil Concentration on LiquidSmokedVacuum-Packed Rainbow Trout (Oncorhynchus mykiss Walbaum, 1792) FilletsDuring Chilled Storage.Food Chemistry Journal. 128:683-688.

Badan Ketahanan dan Keamanan Pangan [BKKP] Yogyakarta. 2012. Data Kandungan Gizi Bahan Pangan dan Olahannya. Yogyakarta[BKKP] Badan Ketahanan dan Keamanan Pangan Yogyakarta. 2012. Data Kandungan Gizi Bahan Pangan dan Olahannya. Yogyakarta. 
Badan Standarisasi Nasional. 2009. Spesifikasi Produk Ikan Asap. SNI2725.(1)1.2009. Badan Standardisasi Nasional, Jakarta.

Cardinal, M., Cornet, J., Serot, T., Baron, R. 2006. Effects of the Smoking Process on Odour Characteristics of Smoked Herring (Clupea harengus) and Relationships with Phenolic Compound Content. Food Chem. 96:137-146. Dinas Perikanan dan Kelautan [DKP], 2013. Profil Tangkapan Provinsi Gorontalo.DKP Provinsi Gorontalo.

Dwiyitno, Rudi, R. 2006. Studi Penggunaan Asap Cair untuk Pengawetan Ikan Kembung (Rastrelliger neglectus) Segar. Jurnal Pascapanen dan Bioteknologi. Kehutanan dan Perikanan. 1(2):143-148.

Ernawati. 2012. Efek Antioksidan Asap Cair terhadap Sifat Fisiko Kimia Ikan Gabus (Ophiocephalus striatus) Asap Selama Penyimpanan. Universitas Yudharta Pasuruan. Jurnal Teknologi Pangan. 4(1).

Fauzya, Salehka, Hadi, Fredy, S. 2012. Identifikasi Sistem Perikanan Teri di Desa Sungsan Banyuasin Sumatera Selatan. Prosiding Insinas. 2012: 122-126.

Guillen, M.D., Sopelana, P., Partearroyo, M.A. 2000. Polycyclic Aromatic Hydrocarbons in Liquid Smoke Flavorings Obtained From Different Types of Wood, Effect of Storage in Polyethylene Flasks on Their Concentrations. J Agric Food Chem. 48:5083-6087.
Gumanti, F.M. 2006. Kajian sistem produksi destilat asap tempurung kelapa dan pemanfaatannya sebagai alternatif bahan pengawet mie basah. Skripsi. FPIK.IPB.Bogor.

Haras, A. 2004. Pengaruh Konsentrasi Asap Cair dan Lama Perendaman Terhadap Mutu Fillet Cakalang (Katsumonus pelamis L) Asap yang Disimpan Pada Suhu Kamar. Skripsi. Bogor: Institut Pertanian Bogor.

Moejiharto, Chamidah, A., Tri, E. 2000. Pengaruh lama Perendaman dan Penyimpanan lkan Bandeng Asap dengan Larutan Asap Cair Terhadap Nilai Aw, tekstur, Organoleptik dan Mikrobiologi. Universitas Brawijaya. Malang.

Rahman, M. S. 2007. Osmotic Dehydration of Foods. In: Rahman, M. S. (ed.) Handbook of Food Preservation, 2nd ed. 2nd ed.: CRC Press.

Rasyda, H.P. 2013. Penggunaan Asap Cair Tempurung Kelapa dalam Pengawetan Ikan Bandeng. Skripsi. Fakultas Matematika dan IImu Pengetahuan Alam. Universitas negeri semarang.

Refilda, Indrawati. 2008. Penyuluhan Penggunaan Garam dan Asap Cair Untuk Menambah Cita Rasa dan Kualitas Ikan Bilih (Mystacoleuseus padangensis) Dari Danau Singkarak Dalam Meningkatkan Perekonomian Rakyat. DP2M Dikti Depdiknas Program IPTEKS. Fakultas MIPA UniversitasAndalas.

Sulistijowati, R., Djunaedi, O.S., Nurhajati, J., Afrianto, E., Udin, Z. 2011. Mekanikme Pengasapan Ikan. 
Universitas Padjajaran. ISBN 978602-8743860.

Sumintono, B., Widhiarso, W. 2013. Aplikasi Model Rasch untuk Penelitian IImuIImu Sosial. TrimKom. Jakarta.

Swastawati, F. 2008. Qualityand Safety of Smoked Catfish (riestal assinus) Using Paddy Chaff and Coconut Shell Liquid Smoke. Journal of Coastal Development. 12(1): 47 - 55.
Tuina, F. 2013. Penentuan Lama Pengeringan dan Laju Perubahan Mutu Nike (Awaous melanocephalus) Kering. Jurnal Nike. 3(1):1-10.

Yulstiani, R. 2008. Asap Cair Sebagai Bahan Pengawet Alami Pada Produk Daging dan Ikan. UPN Veteran Jawa Timur Press. Surabaya. 